\title{
LETTER TO Editor \\ Comment on “Diffuse TTF-1 expression in a CASE of Merkel Cell carcinoma”
}

\author{
Piotr Czapiewski ${ }^{1,2}$, Wojciech Biernat ${ }^{1}$
}

${ }^{1}$ Department of Pathomorphology, Medical University of Gdansk, Gdansk, Poland

${ }^{2}$ Department of Pathology, Otto-von-Guericke University Magdeburg, Magdeburg, Germany

Der Editor,

we read with great interest the recent paper in "Polish Journal of Pathology" entitled "Diffuse TTF-1 expression in a case of Merkel cell carcinoma". We have recently published our observations concerning TTF-1 expression in combined Merkel cell carcinoma (MCC) [1] and we would like to share our opinion/ hypothesis about this phenomenon.

TTF-1 expression has long been believed to exclude the diagnosis of MCC. However, since the first description of TTF-1 positive MCC in 2008 [2, 3], a few such cases have been reported. If combined MCC is included, expression of TTF- 1 seems not to be infrequent, as in the largest published series 4/15 (27\%) presented expression of TTF-1 [4]. In our report, TTF-1 expression was present to a variable extent in $4 / 5(80 \%)$ cases, and peculiarly in two cases also in the squamous cell carcinoma component [1]. Combined MCC differs in many aspects from the conventional MCC: being Merkel cell polyomavirus (MCPV) negative, showing high expression of p53 and a low level of $\mathrm{Rb} 1$ and a much higher number of mutations $[4,5$, 6]. MCPV-negative MCCs overlap to some extent in biology and genetics with the combined MCC, as they present TP53 mutations and a high mutation phenotype, with the majority of them showing a UV-signature pattern with $C>T$ transitions $[5,7,8]$. As all TTF-1-positive conventional MCCs developed in very old people in sun-exposed areas $(85, \mathrm{M}$, right frontal scalp [9], 84, lower lip [3], 74, F, right lower leg [10], 88, F, upper lip [11]), we speculate that TTF-1 expression may correlate with chronic UV light exposure but not with MCPV etiology.

Therefore, it would be interesting to know the MCPV, p53 and Rb1 status of the case reported by Iliadis et al. Additionally, identification of the morphological signs of chronic sun exposure (actinic keratosis) in the neighboring skin would be supportive of our hypothesis.

\section{References}

1. Czapiewski P, Majewska H, Kutzner H, et al. TTF-1 and PAX5 are frequently expressed in combined Merkel cell carcinoma. Am J Dermatopathol 2016; 38: 513-516.

2. Ralston J, Chiriboga L, Nonaka D. MASH1: a useful marker in differentiating pulmonary small cell carcinoma from Merkel cell carcinoma. Mod Pathol 2008; 21: 1357-1362.

3. Buresh CJ, Oliai BR, Miller RT. Reactivity with TdT in Merkel cell carcinoma: a potential diagnostic pitfall. Am J Clin Pathol 2008; 129: 894-898

4. Martin B, Poblet E, J Rios JJ, et al. Merkel cell carcinoma with divergent differentiation: histopathological and immunohistochemical study of 15 cases with PCR analysis for Merkel cell polyomavirus. Histopathology 2013; 62: 711-722.

5. Lai JH, Fleming KE, Ly TY, et al. Pure versus combined Merkel cell carcinomas: immunohistochemical evaluation of cellular proteins ( $\mathrm{p} 53, \mathrm{Bcl}-2$, and c-kit) reveals significant overexpression of p53 in combined tumors. Hum Pathol 2015; 46: 1290-1296.

6. Pulitzer MP, Brannon AR, Berger MF, et al. Cutaneous squamous and neuroendocrine carcinoma: genetically and immunohistochemically different from Merkel cell carcinoma. Mod Pathol 2015; 28: 1023-1032.

7. Harms PW, Patel RM, Verhaegen ME, et al. Distinct gene expression profiles of viral- and nonviral-associated merkel cell carcinoma revealed by transcriptome analysis. J Invest Dermatol 2013; 133: 936-945.

8. Harms PW, Vats P, Verhaegen ME, et al. The Distinctive mutational spectra of polyomavirus-negative Merkel cell carcinoma. Cancer Res 2015; 75: 3720-3727.

9. Reddi DM, Puri PK. Expression of focal TTF-1 expression in a case of CK7/CK20-positive Merkel cell carcinoma. J Cutan Pathol 2013; 40: 431-433.

10. Sierakowski A, Al-Janabi K, Dam H, Sood M. Metastatic Merkel cell carcinoma with positive expression of thyroid transcription factor-1 - a case report. Am J Dermatopathol 2009; 31: 384-386.

11. Iliadis A, Koletsa T, Kostopoulos I, Tzioufa V. Letter to the Editor: Diffuse TTF-1 expression in a case of Merkel cell carcinoma. Pol J Pathol 2015; 66: 200-201.

\section{Address for correspondence}

\section{Piotr Czapiewski}

Department of Pathomorphology

Medical University of Gdańsk

Debinki 7

80-952 Gdańsk, Poland

e-mail: czapiewskipiotr@gumed.edu.pl 